\title{
Responses of the Arabidopsis $K N O X$ and Boron transport gene mutants against the deficiency and overdose of Boron nutrient
}

\author{
WIDI SUNARYO", NURHASANAH \\ Department of Agroecotechnology, Faculty of Agriculture, Mulawarman University. Jl. Paser Balengkong, Gunung Kelua, Samarinda Ulu, Samarinda- \\ 75123, East Kalimantan, Indonesia. Tel./Fax.: +62-541-749159, `email: widi_sunaryo@yahoo.com
}

Manuscript received: 20 December 2015. Revision accepted: 8 March 2016.

\begin{abstract}
Sunaryo W, Nurhasanah. 2016. Responses of the Arabidopsis KNOX and Boron transport gene mutants against the deficiency and overdose of Boron nutrient. Biodiversitas 17: 218-221. Boron is a micro element essential to the plant. Deficiency or overdose of this element result in the stunted plant growth and leads to a decline in the quantity and quality of crop yield. This research was aimed to study the growth response of single homozygous mutant KNOX (stm-GK, knat $1^{\text {bp-9 }}$ ) and Boron transport genes (borl-1, nip5; 1-1) of Arabidopsis thaliana compared to wild type (Col-0) against Boron deficiency and toxicity stress in in vitro experiment. The sterile seeds were inoculated on the $1 / 2 \mathrm{MS}$ medium containing $0 \mathrm{mg} / \mathrm{L}, 3.1 \mathrm{mg} / \mathrm{L}, 6.2 \mathrm{mg} / \mathrm{L}, 9.3 \mathrm{mg} / \mathrm{L}$, and $12.4 \mathrm{mg} / \mathrm{L} \mathrm{H}_{3} \mathrm{BO}_{3}$. Some seedling growth variables such as root length, leaf number and plant height were characterized to observe the response of plant against the treatments. Results showed that different concentration of Boron resulted in a significant effect to seedling growth of all mutants. The loss of BORl gene function as Boron transporter at borl-1 mutant strains and loss of NIP5; 1 gene function as Protein Channel caused severe growth pressures in conditions of media without boron (deficiency). On the other hand, stm-GK and knat $1^{\text {bp-9 }}$ mutants showed no significant growth differences compared to the wild type (Col-O) indicating that the KNOX genes does likely not related to the function of Boron transport genes.
\end{abstract}

Keywords: Boron transport genes, $K N O X$ genes, Boron deficiency and overdose Abbreviations: KNOX (KNOTTED-like homeobox), KNAT (KNOTTED-like from Arabidopsis thaliana), stm (Shoot meristemless), Col (Columbia), NIP (NOD26-like Intrinsic Protein), NASC (The Nottingham Arabidopsis Stock Centre)

\section{INTRODUCTION}

Boron is a micro element that is essential for the plants. Some studies reported that a deficiency of this element caused a decline in crop productivity in both quality and quantity (Miwa et al. 2010), while the excess of this element in the soil would be toxic to plants. Boron plays an important role in the structure and function of plant cell walls (Goldbach and Wimmer 2007). Boron deficiency is also reported to be a major problem in the production of agricultural crops causing stunted plant growth by inhibition of root growth, widening the leaves, and plant fertility (Dell and Huang 1997). Meanwhile, the excess Boron causes plants to show symptoms of poisoning with necrosis along the periphery of the leaf, decreased concentration of chlorophyll, and lower growth and fixation of $\mathrm{CO}_{2}$ /photosynthesis (Nable et al. 1997).

Boron concentration range between deficiency and toxicity is very narrow. Although, it was realized that overcoming Boron deficiency is easier than dealing with the excess Boron by fertilization, but the application of fertilizer can result in Boron poisoning. In addition to Boron fertilization, the application of such technology is very expensive and difficult. Therefore, the understanding of mechanisms of plants regulating the process of adaptation/tolerance to the condition of deficiency or excess/toxicity of boron is very important to deepen in terms of molecular physiology and to develop strategies that can be applied in the future of agriculture, plantation and forestry.

Boron had been known to be required in the structure and function of plant cell walls (O'Neill et al. 2004), in which the Boron constituent 2 Rhamnogalacturonan II molecules, plays a role as the entry of the polysaccharide pectin through Boratediol bond in the Arabidopsis plant cell wall (Kobayashi et al. 1996). Molecular mechanism of boron transport had been reported involving BORl gene of Arabidopsis thaliana which is a Boron transporter (Noguchi et al. 1997). This gene is responsible for the response of plants to change Boron concentration on the plant root surface. Under deficiency condition, BOR1 responsible for boron loading in the xylem cells (xylem loading). Meanwhile, another gene, NIP5;1 also plays an important role as a protein channel that mediates the uptake of boric acid under Boron deficiency condition (Takano et al. 2006). The function of BORI and NIP5;1 gene is the complement each other in an efficient transport of Boron in the deficiency conditions. The other gene, NIP6;1 (the allele of NIP5;1) serves to facilitate and to be a channel for boric acid and is responsible for the distribution of Boron to the leaves (Tanaka et al. 2008).

Based on the report of Sunaryo (2010), the expression of genes associated with both primary and secondary cell wall formation in Arabidopsis was regulated and controlled by members of the KNOX gene family (KNOTTED1-like homoebox) i.e. STM (SHOOT MERISTEMLESS) and KNAT1 (KNOTTED1 -like homoebox in Arabidopsis thaliana 1). In addition, KNAT1 and STM were also the 
regulator of process in division and differentiation of cambial cells into xylem and phloem (Sunaryo and Fischer 2010). STM and KNAT1 are important regulators to promote cell differentiation through repression of xylem fiber differentiation (Liebsch et al. 2014). Through a coexpression analysis, STM/KNAT1 has been proven to also be a regulator of genes that play a important role in the formation of primary and secondary cell walls such as IAA27 (auxin signaling), ATHB-8 (xylem differentiation), NST1 and SND1 (xylem fiber cell identity), SND2 (differentiation of xylem vessel element), IRX1, IRX3, IRX5, COBL4 (cellulose biosynthesis), PME61 (pectin biosynthesis), GAUT12/IRX8 (hemicellulose biosynthesis) (Sunaryo 2010). As a transcription factor, STM/KNAT1 gene plays an important role in the process, structure, and function of plant cell walls, including the structure and function of the cell wall in which the genes control the Boron transport and functions. Therefore, it is very important to study the association of KNOX (STM and KNAT1) with Boron transport genes in relation to the mechanism of plant tolerance against Boron deficiency and toxicity.

This article presented the growth responses of $K N O X$ mutants (stm-GK, knatl $\left.{ }^{b p-9}\right)$ and the Boron transport mutants (bor1-1, nip5;1-1) in Arabidopsis thaliana compared to the wild type (Wild Type; Col-O) against the Boron deficiency and toxicity stress via in vitro experiment.

\section{MATERIALS AND METHODS}

\section{Searching Information of $\mathrm{KNOX}$ and Boron Transport Genes}

To know and deepen the initial information about KNOX (STM and KNAT1) and Boron transport (BORl, NIP5;1, and NIP6;1) genes especially their putative functions, we explored and collected the information from the publicly available website TAIR (www.arabidopsis.org). The locus, identity, insertion site of mutants, and the putative function data were collected to discover the regeneration and mutant selection method.

\section{Plant material and explant preparation}

The wild type and mutant seeds were supplied by Dr. Urs Fischer from Molecular Genetics Laboratory, Department of Forest Genetics and Plant Physiology, Swedish University of Agricultural Sciences, Sweden. The experiment was conducted at the Laboratory of Biotechnology, Faculty of Agriculture, Mulawarman University, East Kalimantan, Indonesia. Seeds of single homozygous mutants of stm-GK, knat ${ }^{\text {bp-9 }}$, bor1-1, nip $5 ; 1$ 1 , and Wild Type Col-O were sterilized with $70 \%$ alcohol for 1 minute, Clorox $25 \%$ for 20 minutes and washed with sterile water 3 times for 1 minute each.

\section{Media preparation}

The sterilized seeds were inoculated in $1 / 2 \mathrm{MS}$ medium (Murishage and Skoog) and treated by $0 \mathrm{mg} / \mathrm{L}, 3.1 \mathrm{mg} / \mathrm{L}$, $6.2 \mathrm{mg} / \mathrm{L}, 9.3 \mathrm{mg} / \mathrm{L}$, and $12.4 \mathrm{mg} / \mathrm{L} \mathrm{H}_{3} \mathrm{BO}_{3}$. Each treatment was repeated 10 times and each bottle of media was inoculated by using 5 seeds. Furthermore, the bottles were incubated in the culture room with the light of 1000-3000 lux and temperature of $22 \pm 2^{\circ} \mathrm{C}$ for germination and growth process.

\section{Observation and data analysis}

Some seedling growth variables such as root length, number of leaves and plant height were observed to look at plant growth responses to the treatments. Observations were made approximately one month after inoculation. Data were analyzed by analysis of variance (ANOVA) and if there was a noticeable/significant effect of the treatment, the differences between mean values will be analyzed using the Least Significant Difference test (LSD) at 5\% level.

\section{RESULTS AND DISCUSSION}

Results of information search showed that almost all mutant lines were produced by insertion of T-DNA both at the exon and intron, except for knatl $^{\text {bp-9 }}$ produced by inserting transposon d-SPM in the intron (Table 1). In Addition, the seeds were segregated lines therefore the homozygous mutant lines were done by screening seeds/seedlings in media containing kanamycin antibiotic (Table 1). Based on Sunaryo (2010) kanamycin concentration effective to screen the Arabidopsis mutant seeds containing T-DNA insertion was $35 \mathrm{mg} / \mathrm{L}$ kanamycin. Meanwhile, the mutant knat ${ }^{b p-9}$ and the wild strain (Wild Type/WT) propagated directly in the field because the seeds were homozygous (Venglat et al. 2002). The background (ecotype) of all strains was the same, Columbia (Col-O). The use of the same ecotype was to ensure that the difference responses in the experiment will not be caused by different background.

The preliminary information from previous studies compiled from TAIR website stated that BOR1 is a protein responsible for Boron transport in Arabidopsis plants exposed by Boron deficiency stress and NIP5;1 is a protein channel for borate acid transportation located in the outer membrane of root cells (Table 2). This protein serves to uptake of Boron in boron deficiency stress condition. KNAT1 and STM, as previously have also been researched by Sunaryo (2010), are KNOX proteins of homeobox gene family regulating the division and differentiation of meristem cells both in apical (buds) and lateral (cambium) meristems including the differentiation of secondary cell wall (Table 2). The same indication had been previously reported by Groover et al (2006) showing that the poplar KNOX gene ARBORKNOX1 (ARK1) and ARBORKNOX2 $(A R K 2)$, which are close homologues of the Arabidopsis $S T M$ and KNAT1 respectively, involved in the regulation of differentiation in vascular development.

The growth of the Arabidopsis plant mutants under conditions of different Boron concentrations is presented at Tables 3, 4, and 5. Boron gave a significant effect on seedling growth of all tested strains of Arabidopsis. From the research it was clearly appeared that different concentrations of Boron resulted in the different growth 
Table 1. Search results of the identity and structure of wild type and mutant plants used in the study

\begin{tabular}{|c|c|c|c|c|c|c|c|}
\hline $\begin{array}{l}\text { NASC } \\
\text { code }\end{array}$ & $\begin{array}{c}\text { Locus in } \\
\text { genome }\end{array}$ & $\begin{array}{l}\text { Gene } \\
\text { name }\end{array}$ & No. SALK lines & Insertion site & $\begin{array}{c}\text { Regeneration } \\
\text { method }\end{array}$ & $\begin{array}{c}\text { Background/ } \\
\text { ecotype }\end{array}$ & $\begin{array}{c}\text { Mutant } \\
\text { name }\end{array}$ \\
\hline N637958 & At4g08150 & $B P / K N A T 1$ & Not SALK Lines & Intron1 (transposon d- & Homozygous & Col- 0 & knat $^{\text {bp-9 }}$ \\
\hline N409575 & At1g62360 & STM & Not SALK Lines & Intron1 (T-DNA) & Seg & Col-0 & stm-GK \\
\hline N522077 & At2g47160 & BORI & SALK_022077 & Exon (T-DNA) & Segr & Col-0 & borl \\
\hline N656927 & At4g10380 & NIP5;1 & SALK_122287C & Intron1 (T-DNA) & Segregation & Col-0 & nip5;1-1 \\
\hline Colombia & - & - & - & - & Homozygous & Col- 0 & Wild Type \\
\hline
\end{tabular}

Table 2. The function of KNOX and transport boron genes in the Arabidopsis plant from literature search

\begin{tabular}{lll}
\hline Gene name & Putative function & Reference \\
\hline BP/KNAT1 & $\begin{array}{l}\text { DNA binding, DNA-dependent, cell fate commitment, cell fate specification, determination of } \\
\text { bilateral symmetry, floral whorl development, flower morphogenesis, meristem initiation, negative } \\
\text { regulation of biological process, nucleus, organ development, organ morphogenesis, pattern } \\
\text { specification process, polarity specification of adaxial/abaxial axis, protein binding, regulation of } \\
\text { transcription, regulation of transcription, DNA-dependent, sequence-specific DNA binding, sequence- } \\
\text { specific DNA binding transcription factor activity, xylem and phloem pattern formation. }\end{array}$ \\
& $\begin{array}{l}\text { Class I knotted-like homeodomain protein that is required for shoot apical meristem (SAM) formation } \\
\text { during embryogenesis. Protein binding, regulation of flower development, regulation of meristem }\end{array}$ & (TAIR 2015) \\
& $\begin{array}{l}\text { structural organization, regulation of transcription, regulation of transcription, DNA-dependent, } \\
\text { sequence-specific DNA binding, sequence-specific DNA binding transcription factor activity, } \\
\text { specification of floral organ identity, stem cell maintenance, xylem and phloem pattern formation. }\end{array}$ \\
& $\begin{array}{l}\text { Boron transporter. Protein accumulates in shoots and roots under conditions of boron deficiency and is } \\
\text { degraded within several hours of restoring boron supply. Localized to the plasma membrane under B }\end{array}$ & (TAIR 2015) \\
& $\begin{array}{l}\text { limitation, and to the cytoplasm after B application before degradation. Under high-boron is } \\
\text { transported to the vacuole for degradation. Borate efflux transmembrane transporter activity, borate } \\
\text { transmembrane transporter activity, borate transport, and response to boron-containing substance. }\end{array}$ \\
& $\begin{array}{l}\text { Boric acid channel. Essential for efficient Boron uptake and plant development under Boron } \\
\text { limitation. Localized preferentially in outer membrane domains of root cells. Borate transmembrane } \\
\text { transporter activity, borate transport, borate uptake transmembrane transporter activity, cellular } \\
\text { response to boron-containing substance levels, response to boron-containing substance, and water } \\
\text { channel activity. }\end{array}$ \\
\hline
\end{tabular}

and responses (Tables 3, 4, and 5). On the condition of absence of Boron, plants were not able to grow perfectly even tended to be stunted indicated by the small number of leaves, short plant height and root length. In normal concentration of Boron, plants grew well, even when the Boron concentration was increased a half time, the plants could achieve the highest growth. The application of Boron at the highest level $(12.4 \mathrm{mg} / \mathrm{L})$ led to a decrease in plant growth (Tables 3, 4, and 5). It indicates that in the deficiency conditions (without Boron), plants were not able to grow well in all mutants or wild strains tested. Boron deficiency results in the cessation of root elongation, reduced leaf expansion and the loss of fertility (Loomis and Durst 1992; Marschner 1995; Dell and Huang 1997) and it most likely influences the cell elongation rather than cell division (Dell and Huang 1997).

In contrast to the condition, an overdose of Boron concentration caused problems in plant growth. Among all mutant strains tested, the deficiency conditions (without Boron), mutant strains borl;1 experienced a severe growth pressure, followed by nip $5 ; 1-1$. While the stm-GK mutant strains and knat $^{\text {bp-9 }}$ looked no different response compared to the wild type (Col-O) (Tables 1, 2, and 3). This indicates that the loss of gene function in borl; 1 as Boron transporter gene and nip5;1-1 as Protein Chanel for Borate ions on Boron deficiency conditions, has led to the loss of plant ability to tolerate the Boron deficiency. On the other hand, overdose of Boron has no effect on plant growth. The excess Boron causes a toxicity to plants shown by necrosis of marginal regions of leaves, decreased chlorophyll concentrations, reduced growth and decreased $\mathrm{CO} 2$ fixation (Nable et al. 1997).

The fact that there were no differences between the mutant strains of knat $^{\text {bp }}$ and $s t m-G K$ with and wild type indicates that the $K N O X$ genes is probably not related to the function of genes associated with Boron transport. However it is still too early to conclude, because testing at the level of the double mutant and gene expression test will prove this early preliminary results. 
Table 3. Effect of Boron deficiency and overdose to the leave number of Boron transport (bor1; 1 and nip5;1-1) and KNOX $\left(\mathrm{stm}-\mathrm{GK}\right.$ and knat $^{\text {bp-9 }}$ ) mutant strains of Arabidopsis thaliana

\begin{tabular}{|c|c|c|c|c|}
\hline \multirow[b]{2}{*}{$\begin{array}{l}\text { Boron } \\
\text { concentration }\end{array}$} & \multicolumn{4}{|c|}{ Mutant strains } \\
\hline & Col-O & $\begin{array}{l}\text { stm- } \\
\text { GK }\end{array}$ & knat1 $_{9}^{\text {bp- }}$ & $\begin{array}{cc}\text { bor1; } & \text { nip5;1- } \\
1 & 1\end{array}$ \\
\hline$\overline{\text { B0 (0 mg/L) (deficiency) }}$ & $5.00 \mathrm{~b}$ & $4.67 \mathrm{~b}$ & $5.00 \mathrm{~b}$ & $4.00 \mathrm{a} 4.67 \mathrm{a}$ \\
\hline B1 (3.1 mg/L) & $6.67 \mathrm{~b}$ & $6.33 \mathrm{~b}$ & $6.67 \mathrm{~b}$ & 4.67 a $5.00 \mathrm{ab}$ \\
\hline B2 (6.2 mg/L) (normal) & $7.00 \mathrm{~b}$ & $6.67 \mathrm{~b}$ & $7.33 \mathrm{~b}$ & 5.67 a 5.67 a \\
\hline B3 (9.3 mg/L) & $8.33 \mathrm{c}$ & $7.67 \mathrm{~b}$ & $7.67 \mathrm{~b}$ & 6.33 a $7.00 \mathrm{ab}$ \\
\hline $\begin{array}{l}\text { B4 }(12.4 \mathrm{mg} / \mathrm{L}) \\
\text { (overdose) }\end{array}$ & $6.67 \mathrm{ab}$ & $7.33 \mathrm{~b}$ & $7.33 \mathrm{~b}$ & 6.00 a $6.67 \mathrm{ab}$ \\
\hline
\end{tabular}

Note: The mean values followed by the same letter in the same row are not significantly different in LSD 5\% test.

Table 4. Effect of Boron deficiency and overdose to the plant height (cm) of Boron transport (borl; 1 and nip5;1-1) and KNOX (stm-GK and knat ${ }^{\text {bp-9 }}$ ) mutant strains of Arabidopsis thaliana

\begin{tabular}{|c|c|c|c|c|c|}
\hline \multirow[b]{2}{*}{$\begin{array}{l}\text { Boron } \\
\text { concentration }\end{array}$} & \multicolumn{5}{|c|}{ Mutant strains } \\
\hline & Col-0 & $\begin{array}{c}\text { stm- } \\
\text { GK }\end{array}$ & knatI $^{b p}$ & $\begin{array}{c}\text { bor1 } \\
1\end{array}$ & $\begin{array}{r}i p 5 \\
1\end{array}$ \\
\hline & & $0.57 \mathrm{~b}$ & & $0.37 \mathrm{a}$ & 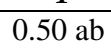 \\
\hline & & & & & \\
\hline $\mathrm{B}$ & 3.5 & $3.60 \mathrm{a}$ & & 3. & $3.80 \mathrm{a}$ \\
\hline & 4.6 & $4.43 \mathrm{~b}$ & $4.30 \mathrm{~b}$ & $3.53 \mathrm{a}$ & $4.07 \mathrm{a}$ \\
\hline $\mathrm{B} 4(12.4 \mathrm{mg} / \mathrm{L})$ & $3.23 \mathrm{~b}$ & $3.00 \mathrm{~b}$ & $2.73 \mathrm{ab}$ & $2.17 \mathrm{a}$ & $2.20 \mathrm{a}$ \\
\hline
\end{tabular}

(overdose)

Note: The mean values followed by the same letter in the same row are not significantly different in LSD 5\% test.

Table 5. Effect of Boron deficiency and overdose to the root length (cm) of Boron transport (borl; 1 and nip5;1-1) and KNOX (stm-GK and knat $^{\text {bp-9 }}$ ) mutant strains of Arabidopsis thaliana

\begin{tabular}{|c|c|c|c|c|c|}
\hline \multirow{2}{*}{$\begin{array}{l}\text { Boron } \\
\text { concentration }\end{array}$} & \multicolumn{5}{|c|}{ Mutant strains } \\
\hline & $c$ & $\begin{array}{c}\text { stm- } \\
\text { GK }\end{array}$ & knatl $^{b p-}$ & $\begin{array}{c}\text { bor1; } \\
1\end{array}$ & $\begin{array}{r}i p 5 \\
1\end{array}$ \\
\hline & & 87 & & & 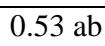 \\
\hline & & & & $2.73 \mathrm{a}$ & 3.30 \\
\hline & 4.2 & $4.33 \mathrm{a}$ & $4.37 \mathrm{a}$ & $3.93 \mathrm{a}$ & 3.90 \\
\hline & 4.70 & $4.90 \mathrm{~b}$ & $4.93 \mathrm{~b}$ & $4.40 \mathrm{ab}$ & 3.60 \\
\hline $\mathrm{B} 4(12.4 \mathrm{mg} / \mathrm{L})$ & $4.47 \mathrm{~b}$ & $4.53 \mathrm{~b}$ & $4.87 \mathrm{~b}$ & $3.57 \mathrm{ab}$ & 3.13 \\
\hline
\end{tabular}
(overdose)

Note: The mean values followed by the same letter in the same row are not significantly different in LSD 5\% test.

To conclude, Boron concentrations gave significant effect on the growth of seedlings of all mutants observed. The loss of gene function of BOR 1 as Boron transporter and the loss of gene function of NIP5;1 as protein channel cause severe growth pressures in the absence of Boron conditions (deficiency). On the other hand, the stm-GK and knat $^{\text {bp-9 }}$ mutants look no different from compared to the a wild strain $(\mathrm{Col}-\mathrm{O})$ in the same conditions indicating that the $K N O X$ genes are likely not related to the function of
Boron transport genes. However, further experiment at molecular level (gene expression) is required to ascertain the fact of this result.

\section{ACKNOWLEDGEMENTS}

This research was supported by the Fundamental Research Grants, Ministry of National Education Republic of Indonesia, 2013-2014. We would to thank to Dr. Urs Fischer for providing the seed materials.

\section{REFERENCES}

Dell B, Huang L. 1997. Physiological response of plants to low Boron. Plant Soil 193: 103-120.

Goldbach HE, Wimmer MA. 2007. Boron in plants and animals: Is there a role beyond cell-wall structure? J PI Nutr Soil Sci 170: 39-48.

Groover AT, Mansfield SD, DiFazio SP, Dupper G, Fontana JR, Millar R, Wang Y. 2006. The Populus homeobox gene ARBORKNOX1 reveals overlapping mechanisms regulating the shoot apical meristem and the vascular cambium. Plant Molecular Biology 61: 917-932.

Kobayashi M. 1996. Two chains of rhamnogalacturonan II are crosslinked by borate-diol ester bonds in higher plant cell walls. Pl Physiol 110: 1017-1020.

Liebsch D, Sunaryo W, Holmlund M, Norberg M, Zhang J, Hall HC, Helizon H, Jin X, Helariutta Y, Nilsson O, Polle A, Fischer U. 2014. Class I KNOX transcription factors promote differentiation of cambial derivatives into xylem fibers in the Arabidopsis hypocotyl. Development 141 (22): 4311-4319.

Loomis WD, Durst RW. 1992. Chemistry and biology of boron. Biofactors 3: 229-239.

Marschner H. 1995. Mineral Nutritin of Higher Plants, 2nd ed. Academic Press, San Diego.

Miwa K, Tanaka M, Kamiya T, Fujiwara T. 2010. Molecular mechanisms of Boron transport in plants: Involvement of Arabidopsis NIP5;1 and NIP6;1. In: Thomas P, Jahn P, Gerd P, Bienert PG. MIPs and their Role in the Exchange of Metalloids. Landes Bioscience and Springer Science+Business Media, Berlin.

Nable RO, Banuelos GS, Paull JG. 1997. Boron toxicity. Plant Soil 193: 181-198.

Noguchi K, Yasumori M, Imai T. 1997. Bor1-1, an Arabidopsis thaliana mutant that requires a high level of boron. Pl Physiol 115: 901-906.

O’Neill MA, Ishii T, Albersheim P, Darvill AG. 2004. Rhamnogalacturonan II: structure and function of a borate crosslinked cell wall pectic polysaccharide. Ann Rev Pl Biol 55: 109-139.

Sunaryo W, Fischer U. 2010. In silico expression analysis of the Arabidopsis KNAT1 gene and its homologs in poplar. In: Kharazipour AR, Schöpper C, Müller C, Euring M (eds.). Review of Forests, Wood Products and Wood Biotechnology of Iran and Germany - Part III. Universitätsdrucke Göttingen, Göttingen, Germany.

Sunaryo W. 2010. Secondary growth in the Arabidopsis hypocotyl. [Ph.D. Dissertation]. Cuvillier Verlag, Göttingen, Germany.

TAIR. 2015. The Arabidopsis Information Resource (TAIR). ABRC, Ohio State University, Columbus $\mathrm{OH}$. www.arabidopsis.org [December 1, 2015]

Takano J, Wada M, Ludewig U. 2006. The Arabidopsis major intrinsic protein NIP5; 1 is essential for efficient boron uptake and plant development under Boron limitation. Plant Cell 2006 18: 1498-1509.

Tanaka M, Wallace IS, Takano J. 2008. NIP6;1 is a boric acid channel for preferential transport of Boron to growing shoot tissues in Arabidopsis. Plant Cell 20: 2860-2875.

Venglat SP, Dumonceaux T, Rozwadowski K, Parnell L, Babic V, Keller W, Martienssen R, Selvaraj G, Datla R. 2002. The homeobox gene BREVIPEDICELLUS is a key regulator of inflorescence architecture in Arabidopsis. Proc Natl Acad Sci USA 99: 74730-74735. 